\title{
Melanocortin-1 receptor gene variants affect pain and $\mu$-opioid analgesia in mice and humans
}

\author{
J S Mogil, J Ritchie, S B Smith, K Strasburg, L Kaplan, M R Wallace, R R Romberg, H Biil, E Y Sarton, \\ R B Fillingim, A Dahan
}

J Med Genet 2005;42:583-587. doi: 10.1136/jimg.2004.027698

Background: A recent genetic study in mice and humans revealed the modulatory effect of MCIR (melanocortin-1 receptor) gene variants on $\kappa$-opioid receptor mediated analgesia. It is unclear whether this gene affects basal pain sensitivity or the efficacy of analgesics acting at the more clinically relevant $\mu$-opioid receptor.

Objective: To characterise sensitivity to pain and $\mu$-opioid analgesia in mice and humans with non-functional melanocortin-1 receptors.

Methods: Comparisons of spontaneous mutant C57BL/6$\mathrm{Mcl} \mathrm{r}^{\mathrm{e} / \mathrm{e}}$ mice to C57BL/ 6 wildtype mice, followed by a gene dosage study of pain and morphine-6-glucuronide (M6G) analgesia in humans with $M C 1 R$ variants.

Results: C57BL/6-Mclr $r^{\mathrm{e} / \mathrm{e}}$ mutant mice and human redheads-both with non-functional MC1Rs-display reduced sensitivity to noxious stimuli and increased analgesic responsiveness to the $\mu$-opioid selective morphine metabolite, M6G. In both species the differential analgesia is likely due to pharmacodynamic factors, as plasma levels of M6G are similar across genotype.

Conclusions: Genotype at MC1R similarly affects pain sensitivity and M6G analgesia in mice and humans. These findings confirm the utility of cross species translational strategies in pharmacogenetics.

$\mathrm{T}$ he melanocortin-1 receptor (MClR) is a rather unlikely candidate to influence acute pain and opioid analgesia, being best known for its role in skin/hair pigmentation ${ }^{1}$ and immunomodulation. ${ }^{2}$ However, quantitative trait locus (QTL) mapping studies in mice led us to the consideration of MCIR involvement in $\kappa$-opioid analgesia in female but not male mice ${ }^{3}$ based on the chromosomal location of the mouse Mclr gene and the demonstration of MClR mRNA and protein in the periaqueductal grey, ${ }^{4}$ a midbrain locus of crucial relevance to endogenous analgesic circuitry. ${ }^{5}$ We found that the $\kappa$-opioid analgesia phenotype of the female Mclr-null C57BL/6-Mclr ${ }^{\mathrm{e} / \mathrm{e}}$ ("recessive yellow", e/e) mutant mouse was similar to that of redheaded women with multiple, protein inactivating $M C I R$ variants. ${ }^{3}$

The clinical utility of this finding is clearly limited by the uncommon application of $\kappa$-opioid acting drugs in pain therapy. On the other hand, drugs acting at the $\mu$-opioid receptor represent the mainstay of clinical treatment of moderate to severe pain. We reasoned that a fuller characterisation of these mutants might reveal other, more clinically relevant phenotypes. To these ends, we tested mutant mice and then humans of various hair colours for their sensitivity to pain and $\mu$-opioid analgesia.

\section{METHODS \\ Subjects}

Naïve, male and female adult (6-10 week old) mice of the C57BL/6J and C57BL/6J-Mc1r ${ }^{\mathrm{e} / \mathrm{e}}$ strains were used. Mice were housed with same sex littermates in groups of two to four. Animal experiments were approved by the local animal care and use committee at McGill University.

A total of 44 Dutch and three Scottish volunteers (23 men, 24 women, median age 22 , range $18-35$ years) participated in this study. All subjects were healthy, and none had participated in pain research previously. All women were on oral contraceptives. Human studies were approved by the local institutional review board at Leiden University Medical Center.

\section{Nociceptive assays}

Mice were tested for their basal sensitivity on six different assays of acute and tonic nociception. Detailed protocols have been published previously. ${ }^{6}$ In the tail withdrawal test, mice were lightly restrained and the latency to vigorous removal of the distal half of the tail from $49^{\circ} \mathrm{C}$ or $47^{\circ} \mathrm{C}$ water was measured. In the hot plate test, mice were placed on a $53^{\circ} \mathrm{C}$ or $50^{\circ} \mathrm{C}$ metal surface within a Plexiglas cylinder, and the latency to first hindpaw lick or shake measured. In the paw withdrawal test, mice were placed atop a glass surface in small Plexiglas enclosures, and a high intensity heat lamp was focused on the right or left mid-plantar hindpaw. The latency to withdraw from the heat stimulus was measured. In the tail clip test, mice were lightly restrained and a binder clip (500 $\mathrm{g}$ force) was applied to their tail near the base. The mouse was immediately removed from the holder onto a table top and the latency to lick, bite, or grab the clip was measured. In the abdominal constriction test, mice received an i.p. injection of $0.9 \%$ acetic acid, were placed in Plexiglas observation cylinders, and the number of reflexive constrictions of the abdominal musculature counted for $30 \mathrm{~min}$. Data in each assay were obtained by only one experimenter.

Human subjects were tested by same sex experimenters. After arrival of human subjects in the laboratory, an arterial line was placed in the left or right radial artery under local anaesthesia (for blood sampling) and an intravenous line was inserted in the contralateral arm (for drug infusion). Acute pain was induced by an electrical current through two surface electrodes (Red Dot, 3M, London, ON, Canada) placed on the skin over the tibial bone (shin bone) of the left leg. The electrodes were attached to a computer interfaced current stimulator. The noxious stimulus was a $10 \mathrm{~Hz}$ tetanic pulse with a duration of $0.1 \mathrm{~ms}$. The intensity of the noxious stimulation was increased from $0 \mathrm{~mA}$ in steps of $0.5 \mathrm{~mA}$ per

Abbreviations: $A D$, antinociceptive dose; $\alpha-M S H, \alpha$-melanocyłe stimulating hormone; AUEC, area under the time-effect curve; M6G, morphine-6-glucuronide; MC1R, melanocortin-1 receptor 
l s (cut off: $128 \mathrm{~mA}$ ). The subjects were instructed to press a button on a control box when no further increase in stimulus intensity was acceptable to them and that current was defined as pain tolerance. Upon pressing the button, the stimulus train ended. After a $1 \mathrm{~h}$ training session, data acquisition began.

\section{Drugs}

Morphine sulfate and morphine-6-glucuronide (M6G) were generously provided by Sabex 2000 (Boucherville, QC, Canada) and CeNeS (Cambridge, UK), respectively. In mice, both drugs were dissolved in saline and administered subcutaneously in an injection volume of $10 \mathrm{ml} / \mathrm{kg}$. The dose given to all human subjects was $0.3 \mathrm{mg} / \mathrm{kg}$ (two thirds given as a bolus over a $90 \mathrm{~s}$ period, the remainder as a continuous infusion over $58.5 \mathrm{~min}$ ).

\section{Analgesia}

Naïve mice were tested at each of four doses $(5,7.5,10$, or $15 \mathrm{mg} / \mathrm{kg}$ ) for morphine, and each of three doses $(5,10$, or $15 \mathrm{mg} / \mathrm{kg}$ ) for M6G, to construct dose-response curves. Sample sizes in these experiments were $n=7-24 /$ genotype/ sex/dose. Mice were tested for baseline sensitivity on the $49^{\circ} \mathrm{C}$ tail withdrawal test, immediately injected with morphine or M6G, and then retested at 15, 30, and 60 min post-injection for morphine, and additionally at 120, 180, 240, and $300 \mathrm{~min}$ post-injection for the longer acting M6G.
Prior to drug infusion in humans, three baseline tests were performed. After the drug infusion was initiated at time $\mathrm{t}=0$, the pain tests were performed at the following times: $t=5$, $10,20,30,40,50,60,65,70,80,90,100,110,120,130,140$, $150,160,170,180,190,200,220,240,260,280,300,320,340$, and $360 \mathrm{~min}$.

\section{Pharmacokinetic analysis}

Mice of both genotypes and both sexes were injected with morphine $(10 \mathrm{mg} / \mathrm{kg})$ or M6G (10 mg/kg), and left undisturbed in their home cages until sacrificed by decapitation at 15, 60, or 180 min post-injection. Trunk blood was collected on ice and immediately centrifuged for $10 \mathrm{~min}$ at 3500/min to isolate plasma, which was then stored at $-20^{\circ} \mathrm{C}$ until analysis. Plasma morphine and M6G concentrations were determined with liquid chromatography tandem mass spectrometry. The lower and upper limits of quantification were set at 1.25 and $5000 \mathrm{ng} / \mathrm{ml}$, respectively. Each drug/ genotype/sex/time condition was run in triplicate.

At fixed times $(\mathrm{t}=2,5,10,20,30,40,50,60,62,65,70,80$, $90,105,120,150,180,240,300$, and $360 \mathrm{~min}$ after start of drug infusion), $5 \mathrm{ml}$ of arterial blood in human subjects was drawn for determination of plasma concentrations of M6G. At time points where blood sampling coincided with pain assessment, the pain testing preceded the sampling. Finally, in each subject, an extra sample of blood was obtained for genotyping. Plasma M6G concentrations were determined as
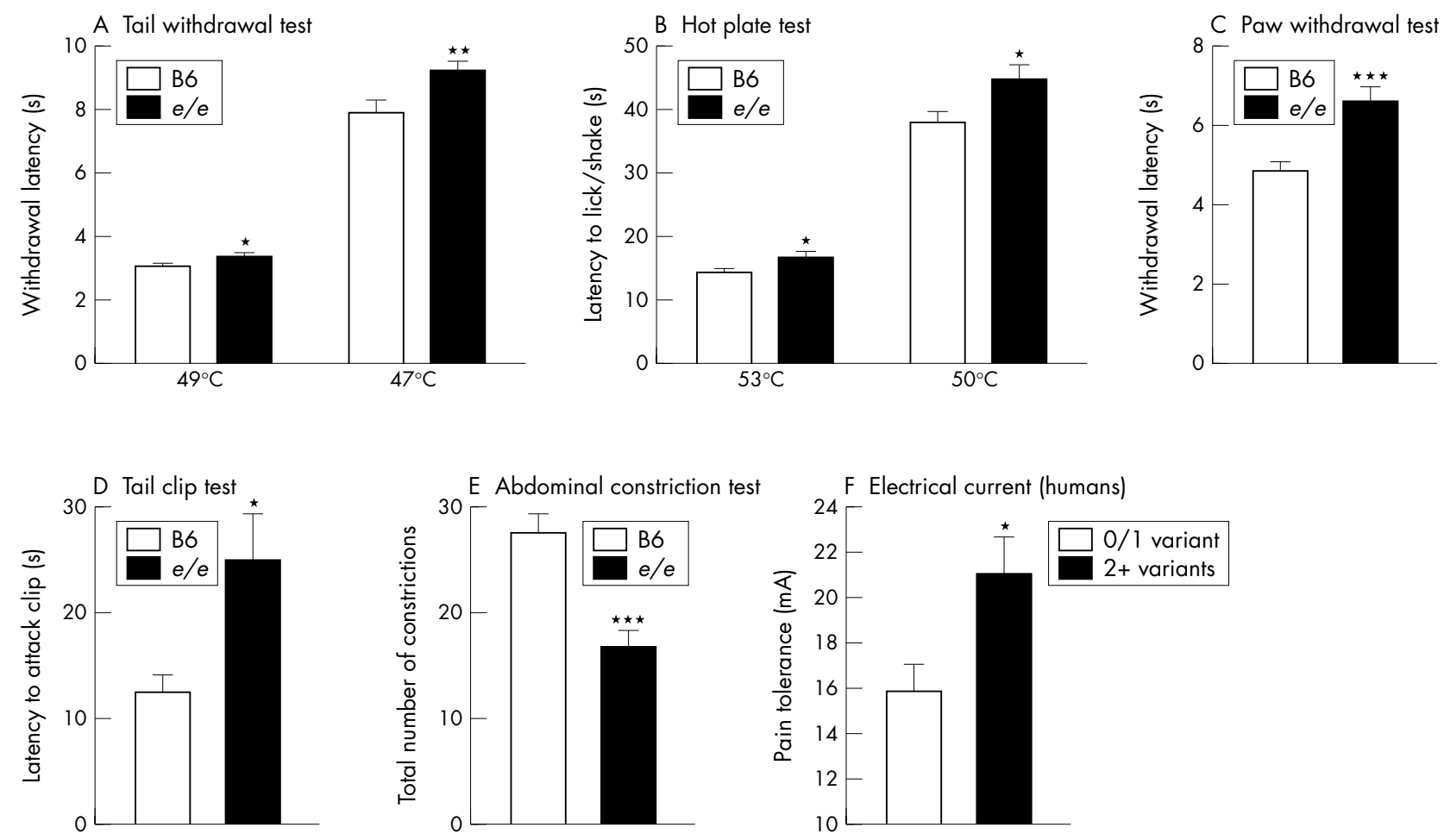

Figure 1 Effect of $M C I R$ functionality on basal nociceptive and pain sensitivity in mice and humans. Graphs A-E compare recessive yellow (e/e) mutant mice of both sexes with their wildtype counterparts, C57BL/6J (B6). Graph F compares human subjects of both sexes with functional MC1Rs (0/1 variant) to red-haired subjects with non-functional MC1Rs (2+ variants). Bars represent mean + SEM in all graphs. Sample sizes in these experiments were $n=9-31 /$ genotype/sex, except for the $49^{\circ} \mathrm{C}$ tail withdrawal test, which represents the compilation of baseline latencies from 2 years of separate experiments using this assay ( $n=72-185 /$ genotype/sex). (A) Latencies to withdraw the distal half of the tail from $49^{\circ} \mathrm{C}$ (left) or $47^{\circ} \mathrm{C}$ (right) water. Values are the mean of eight latency determinations at four time points $(0,30,60,90 \mathrm{~min})$. (B) Latency to lick or shake/flutter a hind paw after being placed on a hot plate set at $53^{\circ} \mathrm{C}$ (left) or $50^{\circ} \mathrm{C}$ (right). (C) Latency to withdraw from a radiant heat source aimed from below at the plantar surface of the hind paw. Values are the mean of 32 separate determinations, each separated by at least $5 \mathrm{~min}$. (D) Latency to attack (that is, attempt to remove) a $500 \mathrm{~g}$ binder clip attached to the tail near the base. (E) Total number of abdominal constrictions (writhes) observed in a $30 \mathrm{~min}$ period after injection of $0.9 \%$ acetic acid. (F) Baseline tolerance of electrical current $\left(10 \mathrm{~Hz}\right.$ pulse; $0.1 \mathrm{~ms}$ duration, $0.5 \mathrm{~mA}$ steps) applied to the skin of the left leg. ${ }^{*} p<0.05 ;{ }^{* *} p<0.01 ;{ }^{* \star *} p<0.001$. Data from both sexes combined are shown; significant effects of genotype were seen in both sexes in all assays except the $49^{\circ} \mathrm{C}$ and $47^{\circ} \mathrm{C}$ tail withdrawal test, where only male e/e mice differed from male B6. 
described above, with the coefficient of variation varying from 4 to $8 \%$ over the calibration range of $2-10000 \mathrm{ng} / \mathrm{ml}$.

\section{Genotyping}

The $M C I R$ polymorphism detection strategy involved sequencing the 5' two thirds of the open reading frame, where all of the known variants occur except for D294H, which was specifically screened for using a Taql loss of digestion strategy. See Mogil et $a l^{3}$ for details.

\section{Data analysis}

Nociceptive assay data in mice were analysed by two way ANOVA (genotype, sex). Where significant interactions were obtained, genotype or sex differences were evaluated by two tailed Student's t test. Half maximal antinociceptive doses $\left(\mathrm{AD}_{50} \mathrm{~s}\right)$ and associated $95 \%$ confidence intervals were calculated from \% analgesia (area under the curve) data using the method of Tallarida and Murray. ${ }^{7}$

For each human subject, the area under the time-effect curves (AUEC) was calculated using the trapezoidal rule and standardised by the length of the study (360 min). The data were separated by genotype with one group consisting of subjects with at least two variant alleles of the $M C 1 R$ gene previously associated with MCIR loss of function (and, thus, red hair) (ins29, R151C, R160W, D294H) and the other group consisting of subjects with the consensus sequence, one variant allele only, or two variant alleles at amino acids not associated with MC1R loss of function (V60L, V92M, and $\mathrm{R} 163 \mathrm{Q})^{8}$ (see table 2 in Appendix 1 for details).

A two way ANOVA (genotype, sex) was performed on baseline pain, AUEC, and plasma M6G concentration data. Where significant interactions were obtained, genotype or sex differences were evaluated by two tailed Student's t test.

\section{RESULTS}

As shown in fig 1, e/e mutants displayed reduced nociceptive sensitivity. On most assays, a significant effect of genotype was observed in both sexes; the exception was the tail withdrawal test, in which only male e/e mice displayed significantly higher latencies. The reduced sensitivity of e/e mutants did not appear to be opioid mediated, since the differences persisted after pretreatment with naloxone ( $10 \mathrm{mg} / \mathrm{kg}$, s.c.) (data not shown).

Next, we constructed analgesic dose-response curves for e/e and C57BL/6 mice of both sexes given systemic morphine (5$20 \mathrm{mg} / \mathrm{kg}$ ) and its bioactive metabolite, M6G (5-15 mg/kg). Although there has been some confusion in the literature, it is now quite clear that M6G acts largely at the $\mu$-opioid receptor, ${ }^{9}$ albeit likely at one coded for by an alternatively spliced transcript of the Oprm gene. ${ }^{10}$ As shown in fig $2 \mathrm{~A}$ and B for M6G (and table 1 in Appendix 1), e/e mutants of both sexes displayed significantly greater inhibition of thermal
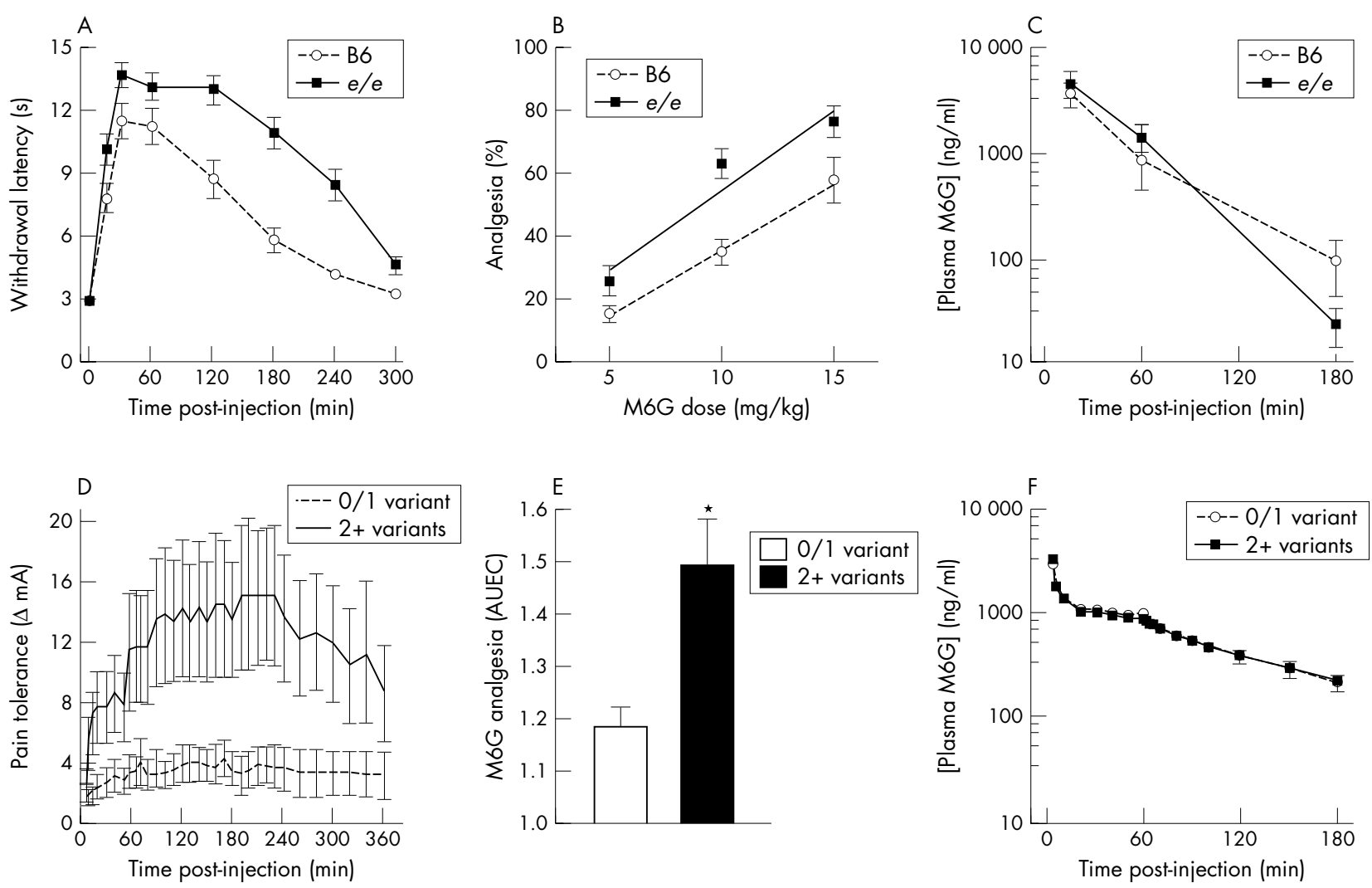

Figure 2 Effect of MCIR functionality on the efficacy of $M 6 G$ at inhibiting thermal nociception in mice and electrical current pain in humans. Graphs A-C compare recessive yellow (e/e) mutant mice of both sexes with their wildtype counterparts, C57BL/6J (B6). Graphs D-F compare human subjects of both sexes with functional MClRs (O/1 variant) to red-haired subjects with non-functional MClRs (2+ variants). Symbols and bars represent mean \pm SEM in all graphs. (A) Latency to withdraw the distal half of the tail from $49^{\circ} \mathrm{C}$ water before and at various time points after injection of $10 \mathrm{mg} / \mathrm{kg}$ (s.c.) M6 G. (B) Doseresponse relationships for $M 6 G(5,10$, or $15 \mathrm{mg} / \mathrm{kg})$ analgesia. Symbols represent \% analgesia, calculated with respect to the area under the time latency curve shown in $A$, using the trapezoidal rule and with reference to a hypothetical mouse with the same baseline latency but displaying cut off ( $15 \mathrm{~s}$ ) latencies at all post-injection time points. (C) Plasma M6G concentrations at 15, 60, and 180 min after injection of $10 \mathrm{mg} / \mathrm{kg} \mathrm{M6G} \mathrm{in} \mathrm{naive} \mathrm{B6} \mathrm{and} \mathrm{e/e} \mathrm{mice.} \mathrm{We}$ also observed no genotype differences in plasma morphine or M6G concentrations after injection of $10 \mathrm{mg} / \mathrm{kg}$ morphine (data not shown). (D) Change in pain tolerance of human subjects at various time points after the administration of $0.3 \mathrm{mg} / \mathrm{kg} \mathrm{M6G}$. (E) M6G analgesia expressed as area under the timeeffect curve (AUEC relative to baseline currents) shown in D. ${ }^{*} p<0.05$. (F) Plasma M6G concentrations in human subjects at various time points after injection of $0.3 \mathrm{mg} / \mathrm{kg} \mathrm{M6G}$. 
nociception from these drugs than did their C57BL/6 counterparts at all doses tested. The M6G data were particularly robust, with differences in both the peak analgesic effect and the duration of analgesia.

Given the strength of the M6G finding in mice, we attempted a translational genetic association study in humans with this clinically useful analgesic. A total of 22 subjects ( 11 men, 11 women) had two or more variant alleles of the MCIR gene in amino acids known to abolish MCIR functionality (R151C, R160W, and D294H); all of these subjects had red hair and fair (type I or II) skin. The remaining 25 subjects ( 12 men, 13 women) had zero or only one variant alleles at these loss of function loci, and thus possessed functional MClRs (see table 2 in Appendix 1), even though seven of these subjects also had red hair (presumably due to genes other than $M C 1 R$ ). Baseline pain tolerance differed significantly between genotypes, with greater currents tolerated by $M C 1 R$ variant subjects, 20.9 (SEM 1.7) $\mathrm{mA}$, compared to control subjects, 15.8 (1.2) $\mathrm{mA}$ $(\mathrm{p}=0.018$; fig $\mathrm{lF})$. There was no significant main effect of sex or genotype $\times$ sex interaction.

Analgesic responses after $\mathrm{M} 6 \mathrm{G}$ were greater in $M C 1 R$ variant subjects compared to control subjects. The areas under the time-effect (pain tolerance relative to baseline) curves were $1.18(0.04) \mathrm{mA}$ for control subjects versus 1.49 (0.09) $\mathrm{mA}$ for $M C 1 R$ variant subjects ( $\mathrm{p}=0.003$; fig $2 \mathrm{D})$. These values indicate that M6G produced an average increase in tolerable current of $18 \%$ (or $4 \mathrm{~mA}$ ) and $49 \%$ (or $10 \mathrm{~mA}$ ) above baseline in control and MClR variant subjects, respectively (fig 2E). There was no significant main effect of sex or genotype $\times$ sex interaction.

The genotypic differences observed were related to the pharmacodynamics of M6G acting at $\mu$-opioid receptors, since plasma M6G concentrations did not differ between genotypes in either mice (fig 2C) or humans (fig $2 \mathrm{~F}$ ) at multiple time points post-M6G injection.

\section{DISCUSSION}

Adequate pain control in acute pain patients is of vital importance. Poor pain relief may result in complications and prolonged hospitalisation, and the patient may ultimately develop chronic pain or complex pain syndromes. ${ }^{11}$ Pain control is often difficult due to large between-patient variability in pain responses and analgesic efficacy. ${ }^{12}$ In this study, we demonstrate a significant link between $M C 1 R$ gene sequence, pain tolerance, and efficacy of the $\mu$-opioid, M6G. In striking agreement with the mouse mutant studies, we observed greater M6G induced analgesic responses in those red-haired humans who are also loss of function "mutants" at the MClR gene.

The observation that in humans and mice, the M6G/MC1R interaction is sex independent contrasts with our earlier finding that $M C 1 R$ status affected pentazocine ( $\kappa$-opioid) analgesia in females only. ${ }^{3}$ Whether these are general differences or are restricted to the specific $\mu$ - and $\kappa$-opioids already tested requires further investigation. The decreased pain sensitivity in MClR non-functioning humans and e/e mice compared to controls suggests that endogenous activation of the MClR may counteract an endogenous pain inhibition system; that is, produce anti-analgesia. Our failure to observe this difference in basal pain sensitivity previously ${ }^{3}$ is likely due to a variable genotypic effect size across different pain modalities (thermal and ischemic pain ${ }^{3} v$ electrical current pain).
Our choice to study the role of $M C 1 R$ in $\mathrm{M} 6 \mathrm{G}$ analgesia in our human population was obvious based on the results of the mouse studies. We believe that these data nicely illustrate the power of direct mouse to human translation in genetic studies of pain. Demonstration of the possible role of $M C 1 R$ in human clinical pain awaits large scale genetic association studies. We suggest that such association studies are more profitably attempted after the successful demonstration of a pharmacogenetic effect against experimental laboratory pain, which can be more carefully controlled.

\section{Authors' affiliations}

J S Mogil, J Ritchie, S B Smith, K Strasburg, Department of Psychology and Centre for Research on Pain, McGill University, Montreal, Canada L Kaplan, M R Wallace, Department of Molecular Genetics and Microbiology, University of Florida, Gainesville, FL, USA

R R Romberg, H Bijl, E Y Sarton, A Dahan, Department of Anesthesiology, Leiden University Medical Center, Leiden, The Netherlands

R B Fillingim, University of Florida College of Dentistry and Gainesville VA Medical Center, Gainesville, FL, USA

This work was supported by US PHS grant DA15191 and the Canada Research Chairs and Canada Foundation for Innovation programs (JSM), the Children's Miracle Network, UF Research Opportunity Fund and the Hayward Foundation (MRW), and US PHS grant NS41670 (RBF). CeNeS Ltd provided financial support for the measurement of the human M6G blood concentrations.

Competing interests: none declared

Correspondence to: Jeffrey S Mogil, Department of Psychology, McGill University, 1205 Dr. Penfield Ave, Montreal, QC, Canada H3A 1B1; jeffrey.mogil@mcgill.ca

Revised version received 10 January 2005

Accepted for publication 29 January 2005

\section{REFERENCES}

1 Rees JL, Birch-Machin M, Flanagan N, Healy E, Phillips S, Todd C. Genetic studies of the human melanocortin-1 receptor. Ann N Y Acad Sci 1999:885: 134-42

2 Tatro JB. Receptor biology of the melanocortins, a family of neuroimmunomodulatory peptides. Neuroimmunomodulation 1996:3:259-84.

3 Mogil JS, Wilson SG, Chesler EJ, Rankin AL, Nemmani KV, Lariviere WR, Groce MK, Wallace MR, Kaplan L, Staud R, Ness TJ, Glover TL, Stankova M, Mayorov A, Hruby VJ, Grisel JE, Fillingim RB. The melanocortin-1 receptor gene mediates female-specific mechanisms of analgesia in mice and humans. Proc Natl Acad Sci U S A 2003;100:4867-72.

4 Xia Y, Wikberg JES, Chhajlani V. Expression of melanocortin 1 receptor in periaqueductal gray matter. Neuroreport 1995;6:2193-6.

5 Sandkuhler J. The organization and function of endogenous antinociceptive systems. Prog Neurobiol 1996;50:49-81.

6 Mogil JS, Wilson SG, Bon K, Lee SE, Chung K, Raber P, Pieper JO, Hain HS, Belknap JK, Hubert L, Elmer Gl, Chung JM, Devor M. Heritability of nociception. I. Responses of eleven inbred mouse strains on twelve measures of nociception. Pain 1999;80:67-82.

7 Tallarida RJ, Murray RB. Manual of pharmacologic calculation. New York: Springer, 1981.

8 Schaffer JV, Bolognia JL. The melanocortin-1 receptor: red hair and beyond. Arch Dermatol 2001;137:1477-85.

9 Romberg R, Sarton E, Teppema L, Matthes HWD, Kieffer BL, Dahan A. Comparison of morphine-6-glucuronide and morphine on respiratory depressant and antinociceptive responses in wild type and $\mu$-opioid receptor deficient mice. Br J Anaesth 2003;91:862-70.

10 Schuller AGP, King MA, Zhang J, Bolan E, Pan YX, Morgan DJ, Chang A, Czick ME, Unterwald EM, Pasternak GW, Pintar JE. Retention of heroin and morphine-6 $\beta$-glucuronide analgesia in a new line of mice lacking exon 1 of MOR-1. Nat Neurosci 1999;2:151-6.

11 Carr DB, Goudas LC. Acute pain. Lancet 1999;353:2051-8.

12 Aubrun F, Langeron O, Quesnel C, Coriat P, Riou B. Relationships between measurement of pain using visual analog score and morphine requirements during postoperative intravenous morphine titration. Anesthesiology 2003;98:1415-21. 


\section{APPENDIX 1}

Table 1 Half-maximal analgesic doses $\left(A D_{50} s\right)$ and potency ratios for morphine $(5,7.5,10 \text {, and } 15)^{*}$ and $M 6 G(5$, 10 , and $15 \mathrm{mg} / \mathrm{kg})+$ inhibition of $49^{\circ} \mathrm{C}$ tail withdrawal nociception in e/e mutant mice and their wildtype counterparts, $\mathrm{C} 57 \mathrm{BL} / 6$

\begin{tabular}{|c|c|c|c|c|c|}
\hline Drug & Strain & Sex & $A D_{50}, \mathrm{mg} / \mathrm{kg} \ddagger$ & Potency ratio, sex§ & Potency ratio, genotype \\
\hline \multirow[t]{3}{*}{ Morphine } & $\begin{array}{l}\text { C57BL/6 } \\
\text { M only } \\
\text { F only }\end{array}$ & $M+F$ & $\begin{array}{l}11.3(10.2 \text { to } 12.6) \\
10.7(8.9 \text { to } 12.5) \\
11.9(10.4 \text { to } 13.6)\end{array}$ & $0.9(0.7$ to 1.1$)$ & \\
\hline & $\begin{array}{l}\text { e/e } \\
\text { M only }\end{array}$ & $M+F$ & $\begin{array}{l}8.5(7.8 \text { to } 9.3) \\
8.3(7.2 \text { to } 9.6)\end{array}$ & & $\begin{array}{l}1.3(1.2 \text { to } 1.5)^{\text {** }} \\
1.3(1.0 \text { to } 1.6)^{\text {** }}\end{array}$ \\
\hline & F only & & 8.7 (7.7 to 9.8$)$ & 1.0 (0.8 to 1.2 ) & $1.4(1.2 \text { to } 1.6)^{* *}$ \\
\hline \multirow[t]{6}{*}{ M6G } & C57BL/6 & $\mathrm{M}+\mathrm{F}$ & 13.3 (11.4 to 15.5 ) & & \\
\hline & M only & & 17.8 (13.1 to 24.3 ) & & \\
\hline & F only & & $11.9(9.7$ to 14.4$)$ & $1.5(1.0 \text { to } 2.2)^{*}$ & \\
\hline & $e / e$ & $M+F$ & $8.0(7.1$ to 9.0$)$ & & $1.7(1.4 \text { to } 2.0)^{* *}$ \\
\hline & M only & & $9.0(7.6$ to 10.6$)$ & & $1.7(1.3 \text { to } 2.4)^{* *}$ \\
\hline & F only & & $6.9(5.7$ to 8.3$)$ & $1.3(1.0 \text { to } 1.7)^{*}$ & $1.6(1.3 \text { to } 2.2)^{* *}$ \\
\hline
\end{tabular}

*Based on \% analgesia scores over a 60 min testing period; three way ANOVA revealed significant main effects of genotype $\left(F_{1,195}=13.3, p<0.001\right)$ and dose $\left(\mathrm{F}_{4,195}=37.1, \mathrm{p}<0.001\right)$ only.

tBased on \% analgesia scores over a 300 min testing period; three way ANOVA revealed significant main effects of genotype $\left(F_{1,101}=20.9, p<0.001\right)$ and dose $\left(F_{2,195}=37.9, p<0.001\right)$ only. $A D_{50}$ s calculated on data from the first $60 \mathrm{~min}$ (not shown) revealed $M 6 G$ to be approximately twice as potent as morphine in all groups in this assay.

$\mp A D_{50} s$ calculated using the method of Tallarida and Murray; ${ }^{7}$ values in parentheses are $95 \%$ confidence intervals.

SThe ratio of male $A D_{50}$ :female $A D_{50}$; values in parentheses are $95 \%$ confidence intervals.

The ratio of C57BL6 $A D_{50}: \mathrm{e} / \mathrm{e} A \mathrm{D}_{50}$; values in parentheses are $95 \%$ confidence intervals.

${ }^{* *}$ Significantly different from 1.0, $p<0.05$.

$F$, female; $M$, male.

Table 2 Human subject genotypes and phenotypes

\begin{tabular}{|c|c|c|c|c|}
\hline Genotype & $\begin{array}{l}\text { No. of } \\
\text { variants }\end{array}$ & Genotype* & n $(\%)+$ & Phenotype \\
\hline +/+ (consensus sequence) & 0 & $0 / 1$ & $10(21 \%)$ & All non-redhead \\
\hline $\mathrm{V} 60 \mathrm{~L} /+$ & 1 & $0 / 1$ & $2(4 \%)$ & Both non-redhead \\
\hline V92M/+ & 1 & $0 / 1$ & $1(2 \%)$ & Non-redhead \\
\hline R151C/+ & 1 & $0 / 1$ & $3(6 \%)$ & 1 Non-redhead; 2 redheads \\
\hline R160W/+ & 1 & $0 / 1$ & $3(6 \%)$ & 2 Non-redheads; 1 redhead \\
\hline V6OL/V6OL & 2 & $0 / 1$ & $1(2 \%)$ & Non-redhead \\
\hline $\mathrm{V} 60 \mathrm{~L} / \mathrm{V} 92 \mathrm{M}$ & 2 & $0 / 1$ & $1(2 \%)$ & Non-redhead \\
\hline $\mathrm{V} 60 \mathrm{~L} / \mathrm{D} 294 \mathrm{H}$ & 2 & $0 / 1$ & $1(2 \%)$ & Redhead \\
\hline V92M/D294H & 2 & $0 / 1$ & $1(2 \%)$ & Redhead \\
\hline R151C/R163Q & 2 & $0 / 1$ & $1(2 \%)$ & Redhead \\
\hline $\mathrm{R} 160 \mathrm{~W} / \mathrm{R} 163 \mathrm{Q}$ & 2 & $0 / 1$ & $1(2 \%)$ & Redhead \\
\hline ins $29 /$ ins 29 & 2 & $2+$ & $1(2 \%)$ & Redhead \\
\hline R151C/R151C & 2 & $2+$ & $3(6 \%)$ & All redheads \\
\hline R151C/R160W & 2 & $2+$ & $12(26 \%)$ & All redheads \\
\hline R151C/D294H & 2 & $2+$ & $1(2 \%)$ & Redhead \\
\hline $\mathrm{R} 160 \mathrm{~W} / \mathrm{R} 160 \mathrm{~W}$ & 2 & $2+$ & $4(9 \%)$ & All redheads \\
\hline R151C/R151C and R160W/+ & 3 & $2+$ & $1(2 \%)$ & Redhead \\
\hline Totals & & $\begin{array}{l}0 / 1: 25 \\
2+: 22\end{array}$ & 47 & $\begin{array}{l}\text { Non-redheads: } 18 \\
\text { Redheads: } 29\end{array}$ \\
\hline
\end{tabular}

*Experiments in transfected cell lines have determined that the following MCIR variants are unable to induce cyclic AMP production when stimulated by $\alpha$-melanocyte stimulating hormone $(\alpha-M S H)$ or a long lasting analogue, NDP(Nle, ${ }^{4}$ D-Phe $)$-MSH (see Schaffer and Bolognia): R142H (Arg1 42His), R151C (Arg151Cys), R160W (Arg160Trp), D294H (Asp294His), and the insertion mutations ins29 and ins179. The R142H and insertion mutations are very rare ( $<1 \%$ allele frequency), and were not seen in this study except for one subject homozygous for ins29. Subjects with two (or in one case, three) total variants at ins29, R151C, R160W, and/or D294H (all redheads) were thus classified in the non-functional MCIR genotype group ("2+"). The V6OL (Val6OLeu) and V92M (Val92Met) are somewhat common mutations, but do not lead to MCIR loss of function, and thus subjects with these MCIR variants were classed with the functional MCIR genotype group ("0/1"). R163Q (Argl63Gln) has not yet been tested for CAMP stimulation; we conservatively classified this variant as not affecting MCIR function. It should be noted that the genotypic effect on both baseline sensitivity and $M 6 G$ analgesia is significant at the $p<0.05$ level regardless of the classification of R163Q containing subjects. We also assayed for the K65N (Lys65Asn) and D84E (Asp84Glu) variants, but found none.

tPercentages do not add up to $100 \%$ due to rounding. Allele frequencies in these subjects were: +/+ (wildtype): 31\%; ins29: $2 \%$; V6OL: 6\%; V92M: 3\%; R151C: 27\%; R160W: 26\%; R163Q: 2\%; D294H: 3\%. These values agree well with those previously reported in the literature.

¥Subjects classified as "redheads" had red hair ranging from orange to auburn, fair (type I/II) skin, and blue or green eyes. Twenty two of the 29 redheads (76\%) possessed two or more MCIR inactivating variants, also in excellent agreement with the existing literature. 